\title{
Is it recession-proof? Masstige purchase intention: the moderating effect of perceived economic crisis
}

\author{
Belay Addisu Kassie ${ }^{1}$, and Jounghae Bang ${ }^{2, *}$ \\ ${ }^{1}$ Graduate School of Business Administration, Kookmin University, Seoul, South Korea \\ ${ }^{2}$ College of Business Administration, Kookmin University, Seoul, South Korea
}

\begin{abstract}
The aim of this study is to investigate the effect of economic crisis on consumers' masstige behavioural intention. The study examines the effects of uniqueness, hedonic value, conspicuous consumption and perceived quality on masstige purchase intention, and as well the moderating effect of perceived economic crisis. The study conducts the hierarchical multiple regression analysis. The results show that uniqueness and hedonic values have significant influences on masstige purchase intention, while conspicuous consumption and perceived quality have no influence on masstige purchase intention. In addition, perceived economic crisis has no moderating effect on the relationship between uniqueness, hedonic value, conspicuous consumption, perceived quality and masstige purchase intention. Keywords: Masstige, Economic crisis, Uniqueness, Conspicuous consumption, Hedonic value, Perceived quality
\end{abstract}

\section{Introduction}

The recent economic crisis, caused by COVID-19, impacted the global market, even wellestablished brands and businesses experienced tough times, but how did it affect the masstige sector? The luxury industry has been viewed as recession immune and crisis and uncertainty invulnerable. Intriguingly, past luxury studies witnessed a hybrid trajectory of various luxury product categories. As reported by Vogue Business, the luxury sector has sustained the impact of the 2008 recession hit, although the global personal luxury market shrank by $9 \%$. After more than a decade now, according to [1], the personal luxury goods market dropped by $23 \%$, which is the largest contraction the industry has ever experienced. Despite the turbulence, the luxury market is expected to return to the growth trajectory as evidenced by a rise of 2-3\% in the first quarter of 2021. What about the masstige market? Will the economic downturn tone down the booming masstige segment? Our fear is that the recent recession could lead the middle-class, the growing purchasing group of the new luxury, to abandon masstige goods and switch to subdued product lines. We undertook this study to examine the influence of the recent economic crisis on the purchase intention of masstige goods.

For years, luxury was the privilege and the signal of some people who have superfluous wealth and it was reserved for selected few. However, in the last decades, the luxury market has experienced a new trend [2]. Now, it is no longer remains accessible only to a niche of richest people. An increasing slice of the world's middle-class population began to experience a glimpse of luxurious life [3]. This change is partly attributed to the growing of richness of the mass-class consumers and the democratization of luxury. The rapid economic progress of the

\footnotetext{
* Corresponding author: bangjh@,kookmin.ac.kr
} 
middle-class gives the consumer the financial freedom to enjoy a limited array of luxury. By consequence, many luxury brands, Louis Vuitton, for example, designed reasonably priced prestige products to allure the middle class segment [2]. These paradigm shift in brand positioning from the conventional view of luxury 'luxury only for the rich' to 'luxury to the mass' gives birth to masstige. Masstige is a portmanteau term used to describe Mass and Prestige which holds the charming spot between the mass and the rich [4]. The democratization of luxury or as some researchers prefers to call it, the populence, mass affluence, or accessible luxury, is a recent departure from luxury, which is a downward extension of the traditional luxury. According to the masstige theory, as explained by [2], [4], masstige goods are the finest in terms of quality but they are priced far lower than the super-premium brands. The luxury brand, Giorgio Armani, for instance, has both downward and upward extensions; the brand sells a luxury fashion jeans with Giorgio Armani label to affluent entrepreneurs and professionals and targets the mass youthful audience with Armani Exchange, at a lower price points [5]. Over the last decades, the world has witnessed an upsurge in the demand of both luxury extensions, mainly for less-priced downward luxury extensions. However, in this paper we contend that the Covid-19 pandemic could trim down the private spending of the middle-class population, and may pull back the years of growth of the masstige sector.

When threatened by crisis consumers evaluate the perceived severity of the risk and develop coping mechanism. The Protection Motivation Theory (PMT) may explain individual's protective behavior during crisis situation [6]. According to PMT, individual's decision to engage in threat preventative behavior depends on their evaluation of the two cognitive processes; the threat and coping appraisal. In a threat appraisal individuals evaluate the perceived severity (the degree of seriousness of the potential threat) and the perceived vulnerability (the perceived likelihood of being exposed to the harm). The coping appraisal reflects one's ability to respond to the threat either by adopting or avoiding the threat. The coping appraisal also includes two essential elements; self-efficacy (the capability to perform the coping behavior) and response efficacy (the perceived effectiveness of the coping response in preventing the threat). The model predicts that the motivation to perform protective behavior intensifies with high degree of threat appraisal and risk susceptibility coupled with the likelihood and effectiveness of coping response, which results in a change in behavior.

During periods of economic turndown, people trade-off their choices to what they believe is critically important and look for a new landmarks to challenge the treat [7]. Consequently, businesses change or tone down their target market and tailor their brand positioning to reflect values sought by consumers experiencing recession. Empirical and anecdotal evidences suggest that consumer behave differently during blossoming and economic downturn circumstances. For example, [8] indicated that, over half of the U.S. consumers, either decrease their loyalty or shifted to competitors alternative brands during the 2009 global financial crisis. We undertook this study to examine the influence of the pandemic on the masstige consumer's behavioral intention.

The goal of this study was to examine the impact of uniqueness, hedonic value, conspicuous consumption and perceived quality on masstige purchase intention and further to investigate whether perceived economic crisis moderates the interplay. As such, it is expected that the middle-income consumers, who are targets of the masstige goods, are less likely to desire uniqueness, hedonic value, conspicuous consumption and quality, which may leads to lower purchase intention for masstige brands.

\section{Literature Review and Hypothesis development}

In their Harvard Business Review article, [7] elaborated the concept of "masstige" by focusing on the U.S. middle consumer behavior. They indicated that with the increasing number of middle-class population and the desire of many to possess high-quality goods, 
luxury products became reachable and attainable by the large segment of the market. The notion of luxury and its dimensions are well articulated in past researches, whereas the concept of masstige is still at the premature stage. In his study, Paul [2] developed the masstige pyramid by targeting the Louis Vuitton based in Japan which focuses on the middle and upper-lower class consumers. His work identified luxury brands such as Gucci, Apple, Victoria, Versace, Starbucks, and Louis Vuitton as the best examples that applied the masstige model.

In this study we asserted that companies' departure from the traditional luxury to allure the mass into the world of luxury doesn't make the luxury brand conventional. Luxury was unattainable for the mass fashion oriented young consumers and now a new breed of luxury which is well-designed, well-crafted and even with same label became accessible to the less wealthy segment. Luxury superpowers, Luis Vuitton and Gucci, for example, introduced a line of handbags, which still has the company label, although it is a downward extension [5]. Therefore, we argue that although luxury brands extended downward aiming to maximize their profit by catering the middle class consumer, the approach does not dilute the core brand essence. That is, the new luxury offspring maintains a certain level of uniqueness, emotional value, conspicuousness and quality from the luxury brand. Besides, intriguingly, luxury is very subjective, and it is a matter of perception. What is lavish to one might not necessarily be to another [3]. Hence, more precisely we contend that for the middle-class consumer, owning accessible premium goods could provide a sense of uniqueness, emotional feelings, social status and reliability. Figure 1. below is the research model that we propose.

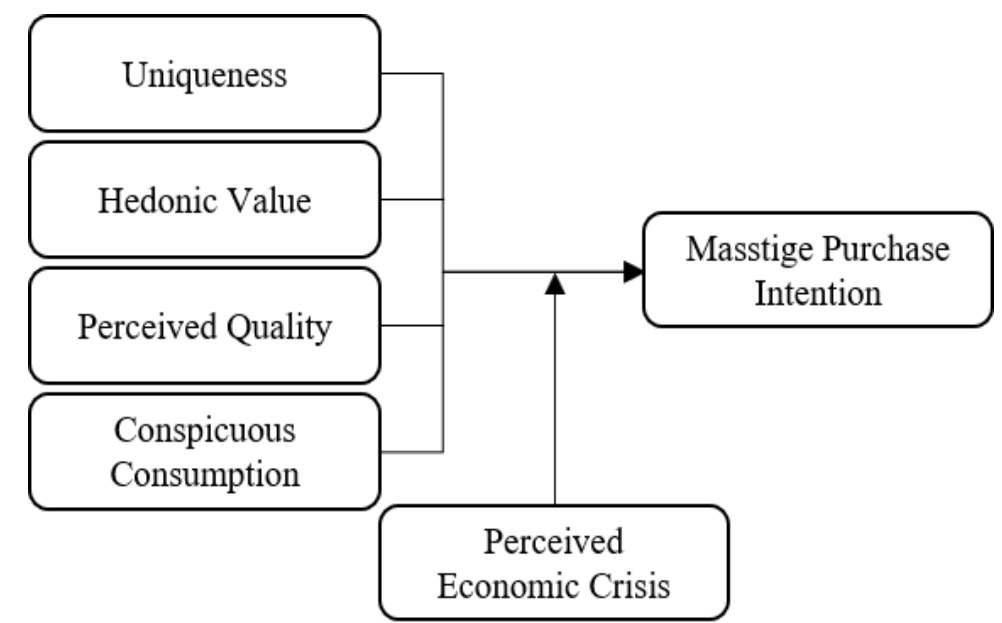

Figure 1. Research Model

Source: Own processing.

\subsection{Uniqueness and Masstige Purchase Intention}

Uniqueness is the behavior of buying distinctive products with the intention of impressing other and creating a difference among others. According to the uniqueness theory individuals tend to change their attitude when they feel higher similarity with others and engage in behaviors that exhibit their difference [9]. Consumers seek to regenerate a unique use for a product when they experience high similarity (vs. low similarity). Consistent with the theory of uniqueness, the conformity behavior study postulates that when the similarity magnitude among others heightens, the desire for conformity decreases proportionally [10]. For instance, preference for 
exclusiveness and unavailable products was rated high when the degree of similarity was experienced as high than moderate. When consumers feel similarity with others, they will reach a verdict to recoup their individuality and uniqueness. Individuals with a higher need for uniqueness tend to adopt new brands more quickly. The theory of social comparison [11] argues that an individual is motivated to compare him/herself with significant others and this comparison triggers desire for uniqueness which may influence consumption of consequent brands. Thus, in this study we conjecture that consumer desire for uniqueness may increase the likelihood of purchasing masstige products. That is, people who desire to feel differentiated from their social group may have strong predisposed to buy masstige brands.

\section{H1: Uniqueness will have a positive effect on masstige purchase intention.}

\subsection{Hedonic value and Masstige Purchase Intention}

The psychological value of the brand dominates hedonistic consumer who responds and reacts emotionally to the brand. The emotional attachment, relationship, and feeling such as excitement, warmth, and fun are more important attributes in consumer consumption behavior. Hedonistic consumption behavior is triggered by the affection and emotional values consumers get by using the product [12]. Possession of masstige is a means of obtaining some aesthetic value such as joy and happiness. Previous studies identified hedonistic need as important luxury purchase parameter. Masstige consumers express themselves by owning emotionally rich products and possession enhances their self-esteem and provides a sense of pleasure. However, hedonic is subjective; what is hedonic to one group may not be perceived the same in another society. For example, British consumers are more emotional oriented than Indian consumes. In contrast, concerning the rating of hedonic and utilitarian value in the U.S and Chinese consumers, a very insignificant difference was evidenced [13]. Hence, in this study we expect that hedonic value may influence the purchase intention of masstige products.

\section{H2: Hedonic value will have a positive effect on masstige purchase intention.}

\subsection{Conspicuous consumption and Masstige Purchase Intention}

Veblen [14] in his book 'The Theory of Leisure Class', defined conspicuous consumption as consumers' willingness to pay more for goods that are rich in displaying wealth and signifies status. Conspicuous consumption is the inspirational process by which consumers motivated to enhance their status in the society by purchasing expensive products, displaying and showing off their wealth. As the concept of conspicuous consumption entails, consumers purchase expensive and distinctive products to display their income level and identify their social status in the reference group [5]. From this perspective, the masstige products serve as a way of expressing symbol. In this study we posit that consumers conspicuous consumption behavior influence the intention to purchase masstige products.

\section{H3: Conspicuous consumption will have a positive effect on masstige purchase intention.}

\subsection{Perceived quality and Masstige Purchase Intention}

Perceived quality is the ability of the product to exhibit superior and excellent performance. Quality is a consequence of individuals' judgment and evaluation of a product [15]. Product quality evaluation consists of two spectrums; consumers' subjective and objective recognition of a product. Objective product quality is the use of prior product experience and knowledge to appraise the overall product benefit, performance and trustworthiness, while perceived quality 
linked with users' feeling, subjective judgment and evaluation of the product intrinsic and extrinsic attributes [16]. In this study we used perceived quality to indicate consumers' subjective evaluation and predisposition to purchase of masstige products.

Masstige brands have better quality and enhance the owner's level of satisfaction, compared to ordinary brands. Even before a direct personal experience of brands, consumers can tell about the superior performance of masstige products. Masstige brands are expected to display the finest brand quality and premium price. Masstige brands such as Starbucks, Coach, and Bath have one thing in common that they emphasis on premium product quality to the mass market and make prestigious brands while maintaining their product affordability [4]. Continuous product quality improvement contributes significantly to masstige purchase intention. The notion is supported by the Louis Vuitton masstige strategy of incessant quality enhancement and modification and a positive result was observed with consumers purchase intention and retention as the company widens the product range and improve its quality [2]. Thus, in this study we posit that consumers' perceived quality may influence the purchase intention of masstige products.

\section{H4: Quality will have a positive effect on masstige purchase intention.}

\subsection{The moderating effect of Perceived economic crisis}

In this study, we argue that perceived economic crisis could play a moderating role in the interplay between the four independent variables and masstige purchase intention. During the great recession period of 2008-2011, many middle-income consumers were extremely hit by the crisis and consumers resist purchasing expensive products, tend to buy low-quality and counterfeit luxury items. Even affluent and high-end consumers avoid luxury during the economic crisis with the view of protecting the psychology of those who used to but no longer affords to buy luxury. Because luxury products are perceived as rich in conspicuous and hedonic value, wealthy luxury consumers considered the consumption of status enhancing products as 'luxury shame' and condemn lavish spending and avoid show off when unemployment intensifies and the social suffering enlarges [8].

The luxury sector was projected to grow in 2020, however, the economic downturn sluggish a decades of progress of various product lines. The pre-pandemic outbreak estimate for both the personal and experiential global luxury was expected to be on a positive trajectory. However, even financially strong and true luxury consumers reserved from making huge investments. Consumers are more frugal and conscious in their spending when experiencing crisis [5]. On the contrary, the financial crisis leads consumers to be selective and purchase single but super quality product than purchasing multiple items [5]. Reaction to economic crisis largely depends on the ratio of the perception of the price of the product and perception of once earnings. Although the world has witnessed an upsurge in the income of the middle-class consumers, the global market and economic volatility caused by COVID19 may have a significant impact on consumers' willingness to buy masstige products. Therefore, in this study we predicted that recession threat could condition the middle-class consumers' need for uniqueness, hedonic value, conspicuousness, and perceived quality resulting in contraction in the masstige shopping experience.

H5: Perceived economic crisis will negatively moderate the relationship between uniqueness (H1), hedonic value (H2), conspicuous consumption (H3), perceived quality (H4) and masstige purchase intention. 


\section{Methodology}

The data was collected by online survey in South Korea. We assumed that college students who are familiar with the subject under investigation could provide useful information to test our predictions, thus, we systematically targeted business major students. Our survey was conducted from May 28 to June 15, 2021. We prepared a survey questionnaire and collected the response using 'Google Form,' and we shared the form to the respondents through 'Kakao Talk,' which is the most popular SNS in South Korea.

The measurement items were adopted from existing literatures and previously validated scales. The constructs were measured using a five-point Likert scale, ranging from 1= strongly disagree to $5=$ strongly agree. The uniqueness construct in this study was measured from [17] and [18] five-item scale measurement items. The items for hedonic value were adopted from [19] and [12], which measures respondent's feeling of emotion in owning masstige goods. As for conspicuous consumption, the constructs were adopted from [2] and [20]. Perceived quality scale was measured using [2] and [21] scale, which indicates individuals' perceived consistency, durability, value for money, and confidence in the quality of masstige brands. The five-item scale developed by [22] and [2] was adapted to measure purchase intention, which measure respondents' likelihood to purchase masstige goods.

For those measurement items, reliability and validity are tested. As shown in the Table 1, $\mathrm{KMO}=0.822$, Bartlett's Test of Sphericity was significant at 0.000 for the factor analysis. The "Total Variance Explained" with the Eigen Value of greater than 1 represents four factors explaining $71.569 \%$ of the model. Cronbach's Alpha $(\alpha)$ checks internal consistency of measurements and assures whether items measure the same scale. According to Saunders et al. (2012), if items and constructs Cronbach's Alpha ( $\alpha$ ) value shows 0.7 or above, items said to have internal consistency. Table 1 explains factor loadings and Cronbach's Alpha $(\alpha)$ score of the constructs and all variables were higher than 0.7 , indicating measurements strong internal consistency.

To test the hypothesized relationships, we used regression analysis. Also, to examine the weakening effect of COVID-19 on consumer masstige consumption, we tested the moderating role of perceived economic crisis using hierarchical multiple regression analysis. More detailed results of the hierarchical multiple regression analysis are shown in Table 4. We analyzed the data using SPSS version 27.

Table 1. Reliability and validity

\begin{tabular}{|c|c|c|c|c|c|}
\cline { 3 - 6 } \multicolumn{2}{c|}{} & \multicolumn{3}{c|}{ Factor Analysis } & Reliability \\
\hline Factor & $\begin{array}{c}\text { Survey } \\
\text { information }\end{array}$ & $\begin{array}{c}\text { Factor } \\
\text { Loadings }\end{array}$ & $\begin{array}{c}\text { Eigen } \\
\text { value }\end{array}$ & $\begin{array}{c}\text { Variance } \\
\text { explained }\end{array}$ & Cronbach's $(\alpha)$ \\
\hline \multirow{2}{*}{ Uniqueness } & UNI1 & 0.841 & 6.944 & 28.933 & 0.826 \\
& UN12 & 0.689 & & & \\
& UNI3 & 0.678 & & & 0.902 \\
Hedonic Value & HED1 & 0.880 & 3.969 & 16.539 & \\
& HED2 & 0.798 & & & \\
& HED3 & 0.717 & & & \\
Conspicuous & CC1 & 0.758 & 2.287 & 9.529 & \\
Consumption & CC3 & 0.655 & & & \\
& CC4 & 0.649 & & & \\
& CC5 & 0.543 & & & \\
\hline \multirow{2}{*}{ Perceived } & PQ1 & 0.541 & & & \\
Quality & PQ2 & 0.887 & 1.544 & 6.431 & \\
& PQ3 & 0.613 & & & \\
\hline
\end{tabular}




\begin{tabular}{|c|c|c|c|c|c|}
\hline & PEC1 & 0.901 & 1.343 & 5.595 & 0.907 \\
Perceived & PEC2 & 0.852 & & & \\
Economic & PEC3 & 0.844 & & & \\
Crisis & PEC4 & 0.840 & & & \\
& PEC5 & 0.721 & & & \\
& PEC6 & 0.585 & & & \\
& PI1 & 0.693 & 1.191 & 4.963 & \\
Purchase & PI2 & 0.784 & & & \\
Intention & PI3 & 0.887 & & & \\
& PI4 & 0.799 & & & \\
\hline & PI5 & 0.451 & & $\mathrm{p}=.000$ \\
\hline
\end{tabular}

Source: Own processing.

\section{Result and Discussion}

\subsection{Characteristics of the sample}

Out of 184 questionnaires distributed, 177 valid responses were utilized for further analysis. As shown in table 2, 48\% of participants were male and $52 \%$ were female. The study participants' age ranged from under 20 to 50 years and above. More than half of the respondents were between the age range of 20-30 (66.7\%) and about one third of the respondents earn a monthly income of less than KRW 1.5 million. Of the sample population, $137(77.4 \%)$ were single households, while the remaining 39 were married.

Table 2. Demographic profile

\begin{tabular}{|c|c|c|c|}
\hline Variable & Classification & Frequency & Percentage \% \\
\hline Gender & $\begin{array}{c}\text { Male } \\
\text { Female }\end{array}$ & $\begin{array}{l}85 \\
92\end{array}$ & $\begin{array}{l}48.0 \\
52.0\end{array}$ \\
\hline Age & $\begin{array}{c}<20 \\
20-30 \\
31-40 \\
41-50 \\
>50 \\
\end{array}$ & $\begin{array}{c}2 \\
118 \\
20 \\
18 \\
18 \\
\end{array}$ & $\begin{array}{c}1.1 \\
66.7 \\
11.3 \\
10.2 \\
10.2 \\
\end{array}$ \\
\hline Income & $\begin{array}{c}\text { Less than KRW 1,500,000 } \\
\text { KRW 1,500,000- KRW } \\
2,500,000 \\
\text { KRW 2,500,001- KRW } \\
3,500,000 \\
\text { KRW 3,500,001- KRW } \\
4,500,000 \\
\text { KWN 4,500,001- KRW } \\
5,500,000 \\
\text { More than 5,500,000 }\end{array}$ & $\begin{array}{c}104 \\
31 \\
10 \\
7 \\
8 \\
16\end{array}$ & $\begin{array}{l}58.8 \\
17.5 \\
5.6 \\
4.0 \\
4.5 \\
9.0 \\
\end{array}$ \\
\hline
\end{tabular}

Source: Own processing. 


\subsection{Hypothesis testing}

We performed hypothesis testing at two stages. First, we performed a regression analysis to examine the effect of independent constructs ( $\mathrm{H} 1, \mathrm{H} 2, \mathrm{H} 3$ and $\mathrm{H} 4)$ on masstige purchase intention. Next, we performed a hierarchical multiple regression analysis to assess the effect of the moderating construct (PEC) (H5) using SPSS.

As shown in Table 3, the regression analysis shows that the values of Variance Inflation Factor (VIF) for all constructs were less than 5.0 and the Tolerance values ranged between 0.633 and 0.762 , indicating the absence of Multicollinearity. The results shown in the table 3 indicates that UNI, HED, CC, and PQ account for $37 \%$ (Adjusted $\mathrm{R}^{2}=0.370$ ) of the variance in the MPI. Regarding the goodness of fit, the analysis of variance (ANOVA) presents strong evidence that factors have a non-zero coefficient and considered fit (F-value $=26.868$, $\mathrm{P}=0.000$ ), and $\mathrm{R}^{2}=0.385$ indicating $38.5 \%$ of the observation were fit for the sample regression line.

Table 3. Regression result

\begin{tabular}{|c|c|c|c|c|c|c|c|}
\hline \multirow[t]{2}{*}{ Model } & \multicolumn{2}{|c|}{$\begin{array}{c}\text { Unstandardized } \\
\text { Coefficients }\end{array}$} & \multirow{2}{*}{$\begin{array}{c}\begin{array}{c}\text { Standardized } \\
\text { Coefficients }\end{array} \\
\text { Beta }\end{array}$} & \multirow[b]{2}{*}{$\mathrm{t}$} & \multirow[b]{2}{*}{ Sig. } & \multicolumn{2}{|c|}{$\begin{array}{c}\text { Collinearity } \\
\text { Statistics }\end{array}$} \\
\hline & $\mathrm{B}$ & S.E. & & & & Tolerance & VIF \\
\hline (Constant) & .683 & .280 & & 2.439 & .016 & & \\
\hline Uniqueness & .249 & .067 & .267 & 3.717 & .000 & .694 & 1.441 \\
\hline Hedonic Value & .379 & .072 & .398 & 5.291 & .000 & .633 & 1.581 \\
\hline $\begin{array}{l}\text { Conspicuous } \\
\text { consumption }\end{array}$ & .043 & .081 & .039 & .529 & .598 & .666 & 1.502 \\
\hline Perceived Quality & .047 & .075 & .043 & .623 & .534 & .762 & 1.312 \\
\hline Goodness of fit & \multicolumn{2}{|c|}{$\mathrm{F}=26.868$} & $\mathrm{P}=0.000$ & $\mathrm{R}^{2}=0.3$ & \multicolumn{3}{|c|}{$5 \quad$ Adjusted $R^{2}=0.370$} \\
\hline
\end{tabular}

Source: Own processing.

The regression table shows uniqueness $(\mathrm{b}=.267, \mathrm{t}=3.717, \mathrm{P}<0.01)$ to have a significant effect on MPI thus, the hypothesis 1 is supported. The finding also shows that hedonic value is a more significant contributor to MPI $(b=.398, t=5.291, \mathrm{P}<0.01)$, which provides strong statistical evidence that there is a significant impact of hedonic value on masstige purchase intention. Thus, $\mathrm{H} 2$ can be supported. In contrast, conspicuous consumption and perceived quality were not significant predictors of masstige purchase intention, indicating both constructs to have insignificant impact on MPI, therefore, H3 and H4 are not supported.

Secondly, we examined the effect of perceived economic crisis as a moderator on the relationship of the four constructs and MPI (the dependent variable) (Table 4). In order to measure the role of PEC and to better understand the moderating effect, we introduced a dummy variable (DPEC; high vs. low perceived economic crisis). In order to examine the moderating effect, we performed a hierarchical multiple regression analysis. The result, as shown in table 4, indicates that PEC has no moderating effect. $\mathrm{R}^{2}$ changes were not significant when PEC was entered in the regression while UNI and HED remained significant to MPI. 
Table 4. Moderating effect of PEC

\begin{tabular}{|c|c|c|c|c|c|c|c|c|c|}
\hline \multicolumn{10}{|c|}{ Model Summary } \\
\hline \multirow[b]{2}{*}{ Model } & \multirow[b]{2}{*}{$\mathrm{R}$} & \multirow[b]{2}{*}{$\begin{array}{c}\mathrm{R} \\
\text { Square }\end{array}$} & \multirow[b]{2}{*}{$\begin{array}{l}\text { Adjusted } \\
\text { R Square }\end{array}$} & \multirow[b]{2}{*}{$\begin{array}{l}\text { Std. Error } \\
\text { of the } \\
\text { Estimate }\end{array}$} & \multicolumn{5}{|c|}{ Change Statistics } \\
\hline & & & & & $\begin{array}{c}\mathrm{R} \\
\text { Square } \\
\text { Change }\end{array}$ & $\begin{array}{c}F \\
\text { Change }\end{array}$ & df1 & $\mathrm{df} 2$ & $\begin{array}{l}\text { Sig. F } \\
\text { Change }\end{array}$ \\
\hline 1 & $.620^{\mathrm{a}}$ & .385 & .370 & .75721 & .385 & 26.868 & 4 & 172 & .000 \\
\hline 2 & $.620^{\mathrm{b}}$ & .385 & .367 & .75942 & .000 & .001 & 1 & 171 & .980 \\
\hline 3 & $.636^{\mathrm{c}}$ & .405 & .373 & .75553 & .021 & 1.441 & 4 & 167 & .223 \\
\hline \multicolumn{10}{|c|}{$\begin{array}{l}\text { a. Predictors: (Constant), Quality, Uniqueness, Conspicuous, Hedonic } \\
\text { Predictors: (Constant), Quality, Uniqueness, Conspicuous, Hedonic, DPEC } \\
\text { Predictors: (Constant), Quality, Uniqueness, Conspicuous, Hedonic, DPEC, } \\
\text { ateractionQuali_DPEC, InteractionUniq_DPEC, InteractionHedon_DPEC, } \\
\text { InteractionConsp DPEC }\end{array}$} \\
\hline
\end{tabular}

Source: Own processing.

\section{Discussion}

The finding showed that uniqueness and hedonic value are significant predictors and have positive effect on masstige purchase intention. However, conspicuous consumption and perceived quality do not influence purchase intention. It indicates that consumer's emotion or need to possess aesthetically rich materials and feeling of uniqueness triggers the predisposition to buy masstige products. The finding is interesting in that consumers who need to feel different from their social group tend to purchase masstige brands. When a product becomes popular, it ceases to be exclusive and thus no longer treated as a status symbol [14]. But, luxury companies and scholars realized the fact that luxury is not about sophistication alone. Louis Vuitton, for example, has managed to deploy the masstige strategy by combining the cachet attribute of the core brand with attainable price to make it available to the mass. They designed the new masstige to appeal the middle-class while maintaining the prestige image and exclusive sentiment of the brand $[23,2]$.

Notwithstanding the change in the income of the middle-class consumers caused by COVID-19 pandemic does not affect the masstige purchase intention. COVID-19 has given stressful and traumatic experience which leads to low self-esteem. According to [24] when people perceive low self-concept they encouraged to acquire self-enhancing and unique products. Thus, individuals' low self-esteem caused by the COVID-19 pandemic could have a spillover effect on the need for uniqueness which may lead to masstige behavioral intention. Similarly, there is no moderating effect of perceived economic crisis on the relationship between CC and MIP. The finding of the study shared some similarities with [5] study such that conspicuousness endures regardless of economic turndown and status seekers tend not to change their consumption trend during recession. However, about three decades ago [25] found that Asian consumers cut back their spending and look for less priced products when times are tough. Consumers reduce their spending in the period of crisis and this cut in consumption is mostly proportional to their income. In contrast, this study supports the work of [5] such that consumers need for conspicuousness remains intact during economic downturn. We also predicted that during the pandemic consumers may prioritize healthrelated issues and become more concerned about safety than aesthetic value resulting in the deferment of masstige spending. However, the result showed the non-significant effect of perceived recession on the link between hedonic value and masstige purchase intention. 


\section{Conclusion}

By employing the Protection Motivation Theory, we posit that the recent economic crisis may weaken consumers' need for uniqueness, hedonic value, conspicuous consumption and desire for quality, resulting consumer to turn away from purchasing masstige goods. That is, when individuals perceive high threat and vulnerability they perform preventive behavior which leads to a change in the consumption behavior. However, intriguingly, quite the reverse to the marketing and psychology literature, our study shows that during the pandemic masstige consumers seems not to turn away from masstige. This implies that consumer's predisposition to purchase masstige is not likely to be mitigated by the economic crisis. Admittedly, COVID-19 has disrupted consumers' consumption pattern.

As with all researches, the findings of this study are not without limitations. We considered masstige handbags, wrest watches and perfume products. Thus, further research is needed to examine the effect of the studied constructs on masstige purchase intention with a large set of product categories. Finally, as discussed in the methodology, because of the pandemic we used students as a sample, and the use of student samples may question the generalizability of the finding to the larger population. Future research with a shopping mall intercept approach may also be needed to address the actual masstige consumer group of the population.

\section{References}

1. Bain \& Company, Global personal luxury goods market on track for recovery [online], Available at https:/www.bain.com/about/media-center/press-releases/2021/Globalpersonal-luxury-goods-market-on-track-for-recovery/ (2021)

2. J. Paul, Masstige model and measure for brand management. European Management Journal, 37(3), 299-312 (2019)

3. M. Kastanakis, G. Balabanis, Between the mass and the class: antecedents of the "bandwagon" luxury consumption behavior. Journal of Business Research, 65(10), 1399-1407 (2012)

4. A. Kumar., J. Paul., A. Unnithan, 'Masstige marketing': a review, synthesis and research agenda. Journal of Business Research, 113, 384-398 (2020)

5. J. Nunes, X., Drèze, Y. Han, Conspicuous consumption in a recession: toning it down or turning it up? Journal of Consumer Psychology, 21(2), 199-205 (2011)

6. S. Youn, J. Lee, J. Ha-Brookshire, Fashion consumers' channel switching behavior during the covid-19: protection motivation theory in the extended planned behavior framework. Clothing and Textiles Research Journal, 39(2), 139-156 (2021)

7. M. Silverstein, N. Fiske, Luxury for the masses. Harvard business review, 81(4), 48-59 (2003)

8. N. Piercy, D. Cravens, N. Lane, Marketing out of the recession: recovery is coming, but things will never be the same again. The Marketing Review, 10(1), 3-23 (2010)

9. H. Fromkin, C. Snyder, The search for uniqueness and valuation of scarcity. Social Exchange, Springer, Boston, MA, 57-75 (1980)

10. I. Abosag, Z. Ramadan, T. Baker, J. Zhongqi, Customers' need for uniqueness theory versus brand congruence theory, the impact on satisfaction with social network sites. Journal of business research, 117, 862-872 (2020)

11. L. Festinger, A theory of social comparison process. Human Relations, 7(1), 117-140 (1954)

12. K. Voss, E. Spangenberg, B. Grohmann, Measuring the hedonic and utilitarian dimensions of consumer attitude. Journal of marketing research, 40(3), 310-320 (2003) 
13. P. Shukla, K. Purani, Comparing the importance of luxury value perceptions in crossnational contexts". Journal of Business Research, 65(10), 1417-1424 (2011)

14. T. Veblen, The theory of the Leisure Class. Boston, MA: Houghton Mifflin, (1973)

15. V. Zeithaml, Consumer perceptions of price, quality, and value: a means-end model and synthesis of evidence. Journal of marketing, 52(3), 2-22 (1988)

16. D. Aaker, Measuring brand equity across products and markets. California management review, 38(3) (1996)

17. K. Tian, W. Bearden, G. Hunter, Consumers' need for uniqueness: scale development and validation. Journal of consumer research, 28(1), 50-66 (2001)

18. Q. Bian, S. Forsythe, Purchase intention for luxury brands: a cross cultural comparison. Journal of Business Research, 65(10), 1443-1451 (2012)

19. J. Sweeney, G. Soutar, Consumer perceived value: the development of a multiple item scale. Journal of retailing, 77(2), 203-220 (2001)

20. Y. Liang, Exploring chinese consumers' luxury value perceptions: development and assessment of a conceptual model. Bournemouth University, (2018)

21. S. Agarwal, R. K Teas, Cross-national applicability of a perceived quality model. Journal of Product \& Brand Management, 11(4), 213-236 (2002)

22. A. Arora, N. Kishor, Factors determining purchase intention and behavior of consumers towards luxury fashion brands in India: an empirical evidence. British Journal of Marketing Studies (BJMS), 7(4), 34-58 (2019)

23. J. Paul, Masstige marketing redefined and mapped: introducing a pyramid model and mms measure. Marketing Intelligence \& Planning, 33, 691-706 (2015)

24. M. Lynn, C. Snyder, Uniqueness seeking. Handbook of positive psychology, Oxford, Oxford University Press, 395-410 (2002)

25. S. Ang, S. Cheng, A. Lim, K. Tambyah, Spot the difference: consumer responses towards counterfeits. Journal of consumer Marketing, 18(3) 219-235 (2001) 